\title{
The Challenges of Multiculturalism and Reality in the Qur'an
}

\author{
Muhammad Iman Maedi ${ }^{1}$, Hamka Hasan ${ }^{2}$ \\ \{muhammad.iman18@mhs.uinjkt.ac.id ${ }^{1}, \underline{\text { Hamka.hasan@uinjkt.ac.id }}{ }^{2}$ \} \\ Graduate School of State Islamic University Sy arif Hiday atullah Jakarta ${ }^{1,2}$
}

\begin{abstract}
Multiculturalism is a phenomenon that emerged in the 1970s, an ideology used in managing a pluralistic society. In practice, this ideology has succeeded in creating peace and prosperity in the country where this ideology was originally created. However, in recent decades, multiculturalism is considered a failure in managing multicultural societies in several countries such as in Europe. Violence, terrorism, racism still occur in these communities. Where the ideology of multiculturalism should make people respect each other, respect one another, and uphold the values of brotherhood. So based on these problems, this article will explain the challenges faced by multiculturalism and how the Qur'an describes multiculturalism and the basic values of multiculturalism.
\end{abstract}

Keywords: Multiculturalism, Failure and Qur'an

\section{Introduction}

Multiculturalism is a phenomenon of the modern world that existed in the 1960s and gained recognition in the 1970s, multiculturalism is an alternative model in order to build a country and overcome and manage the plurality of society (Nurdin:2015).

Then the term multiculturalism becomes an acknowledgment of local culture by respecting other cultures. it becomes an intermediary and also a defender for the oppressed community and also supports the thoughts or beliefs that are belittled(Masduki:2016). Finally, the term multiculturalism in general can be received positively in Indonesia's pluralistic society. The emergence of multiculturalism is based on the need for recognition (Joshua: 2011). 


\section{The background of the emergence of multiculturalis m}

Historically, multiculturalism is a new phenomenon that emerged along with immigrants from Middle Eastern countries to western countries after World War II and then an increase after the 1960s. These immigrants cause changes in the demographic composition such as social, ethnic and cultural, along with the immigrant problems that arise because of differences culture brought by those who are contrary to the principles of cultural values that exist in the countries visited (Reiner: 1996).

As stated by B. Parekh, in the early 1970s the multiculturalism movement appeared first in Canada and Australia, then in the US, UK, Germany and other countries. In the United States, the development of multiculturalism, otherwise known as identity politics, was initiated by the student and youth movement in the second half of the 1960s, which challenged established stereotypes and institutions.

\section{Definition of Multiculturalism}

According to Taylor, multiculturalism is the idea of regulating diversity by applying basic principles on the recognition of diversity itself (politics of regognition). According to Hermandes, multiculturalism is a form of cooperation, equality and appreciation in a world that is increasingly complex and does not return to monoculture. Therefore, multiculturalism is a plurality of relations that contains every minority group vis a vis the majority (majority group) and also in it there is an existential struggle for recognition, equality, equality, and justice(Taylor:2019).

According to Parekh, multiculturalism is the answer to the failure of the three major moral traditions (monism) that are developing in life, namely Greek monism, Christian monism and Classical Liberal monism. One of the keys to multiculturalism, according to him, is the way they view differences which are expressed as deviations (moral pathology)(Jupp, n.d.). According to Bloom, multiculturalism is an understanding, assessment and appreciation of one's culture and respect and curiosity for other people's ethnic cultures. Simply put, multiculturalism is translated as an assessment of the culture of others, not in the sense of agreeing on all aspects of the culture, but trying to see how a particular culture can express values for its own members. 
According to Azyumardi Azra, multiculturalism is a world view which is then manifested in political awareness(Azra:2010).

\section{Multiculturalis m Problems}

The ideology of multiculturalism has been successfully applied since the 1970s in western countries and has become a tool in starting a new chapter in managing and maintaining a mutlicultural society with different cultural, ethnic, national and religious backgrounds. However, in the last two decades there have been many debates because the ideology of multiculturalism is considered to have failed to integrate immigrant groups, especially those who are Muslim. Some of the violence and terrorism committed by extreme groups who are anti-Islam or Islamophobic, then the ideology of multiculturalism is tested and its feasibility is questioned in managing a pluralistic society.

\subsection{Successful Application of Multiculturalism}

The Australian government carried out social and political engineering in the 1970s by implementing multiculturalism as the state ideology. This policy aims to reduce and at the same time stop the conflict of values and norms that occur in each group of society. on the one hand the white people and on the other the immigrants who came to the country. After being implemented, the implementation of this ideology is considered successful in managing and overcoming any existing conflicts, ranging from low levels of political violence, terrorism and religion. The implications of multiculturalism are also seen in every immigrant ethnicity and other religious communities, so that they can be protected and integrated and survive(Jupp:2011).

In America in the 1970s the emergence of multiculturalism was due to efforts to achieve equality in the same public space, but there were various obstacles because the Protestant white cultural features were very different from the cultural patterns of blacks, Native Americans and Indians. , all of whom belong to a minority group. So that Abel said "we are all multiculturalism now" with the intention that what is happening today in the United States is the result of every series of multiculturalism educational processes that have emerged since the 1970s (Tariq:2007). 


\subsection{The Failure of Multiculturalism}

The negative view of multiculturalism says that it is a threat to a nation and the western way of life. The opinion that is optimistic about multiculturalism believes that it can overcome political problems, social rights and economic problems that occur in minorities.

The debate about multiculturalism has failed in Europe since the last three years when the Boston bombing occurred in the attack at Woolwich and was followed by the protest at Stockholl. At that time, the European community thought that the ideology of multiculturalism in Europe had failed to resolve conflicts (Derek:2008).

This statement is even stronger, when in 2002 The New Statesman issued a report regarding the disappearance of the ideology of mutliculturalism, then in 2004 The Independent reported that the commission dor racial equality considered multiculturalism to have ended even though the ideology was still valid at that time.

\section{Multiculturalism in the Qur'an}

In the theological perspective, according to Abdullah Yusuf Ali, which is contained in the letter al-Hujurat verse 13, in that verse there is an explanation of the plurality that exists in this world, a reality and sunnatullah, he continued to explain in his interpretation of The Holy Qur'an that brotherhood is not only dwells on Muslims only but applies to all mankind in essence. The verse is very clear that humans were created from a pair of men and women who have the aim of getting to know and understanding each other's character and being made into different groups.

\subsection{Multiculturalism Values in the Qur'an}

1. Justice (al-is) and Equality (al-musawwa)

(Surah ali Imran verse 18, Qs. Al-Zariyat verse 51, Qs. Al-maidah verse 8, Qs. Al-Araf verse 29, Qs. Mumtahanah verse 8, Qs. Al-Anam verse 152, Qs. An- nis a verse 58, Qs. al-Baqarah verse 124, Qs. ali Imran verse 57).

2. Human Rights (Human Rights) 
(Surah al-An'am verse 151, Qs. Al-Maidah verse 32, Qs. Al-Isra verse 70, Qs. Al-Baqarah verses 30-34, Qs. At-Tin verses 4-6, Qs. Al -Baqarah verse 30, Qs. Ali Imran verse 79, Qs. An-Nisa verse 36, Qs, al-Baqarah verse 177, Qs. An-Nisa verse 92, Qs. Al-Maidah verse 89, Qs. As-Shura verse 21, Qs. Yusuf verse 40, Qs. Al-A'laq verse 1-5, Qs. Az-Zumar verse 9, Qs. Taha verse 114, Qs. Verse 122).

\section{Tolerance}

(Surah al-Baqarah verse 208, Qs. Ar-Rum verse 22, Qs. Al-Isra verse 70, Qs. Al-Maidah verse 32, Qs. Al-An'am verse 98, Qs. An-nisa verse 135, Qs. Al-Maidah verse 8, Qs. Al-Mumtahanah verse 8. Qs, al-Imran verse 64, Qs. An-Nahl verse 152, Qs. Al-Baqarah verse 256.

Tables. These are the basic values of multiculturalism in the verses of the Qur'an

Table 1. Implication values multicultualism from the verses in Qur'an.

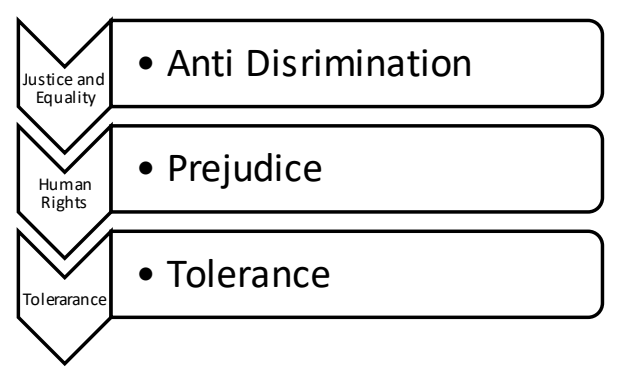

\subsection{Quality of multicultural values in the verses of the al-Qur'an}

Al-Qur'an verses which clearly show the values that form the basis of multiculturalism. Among them Qs. al-Hujurat: 13 which reads: 
يأيها ألناس إنا خلقنكم من ذكر و أنثى وجعلنكم شعوبا وقبائل لتعارفوا إن أكرمكم عند ألله أنقكم إن

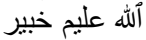

"O people, we actually created you from a man and a woman and made you nations and tribes so that you would know each other. Surely the most noble among you in the sight of Allah is the most devout among you. Allah is All-Knowing, All-Knowing. "

Tables. These are three values form Qs. al-Hujurat verse 13.

Table 2. There are three values form Qs. al-Hujurat verse 13.

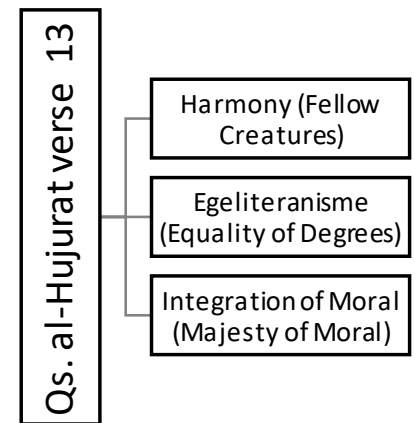

In this verse the values of multiculturalism can be grouped as follows:

Then in Qs. al-Maidah verse 48:

ولو شآء ألله لجعلكم أمة وحدة ولكن لييلوكم فى ماً ءاتنكم فأستنقو ا ألخيرت إلى ألله مرجعكم جميعا فينبئكم بما كنتم فيه تختلفون

"If Allah willed you, he will make you one people (only), but Allah wants to test you against His gift to you, so be competent to do good. Only to Allah will you all return, and He will tell you what you have disputed about."

According to M. Quraish Shihab, the word lauw in the verse shows that making mankind only one kind is not His will, and the word lauw in 
the verse contains an impossibility. And Allah SWT does not want mankind from ancient times until now only one people in all things. Thus Allah SWT created human beings with diversity, so humans can choose their respective religions and beliefs. This is so that humans can compete in doing good and creativity in improving quality with the existence of differences and competitions in this regard (Quraish: 2002).

Tables. These are the basic values of multiculturalism in the Qur'an

Table 3. Basic values of multiculturalism in Qur'an.

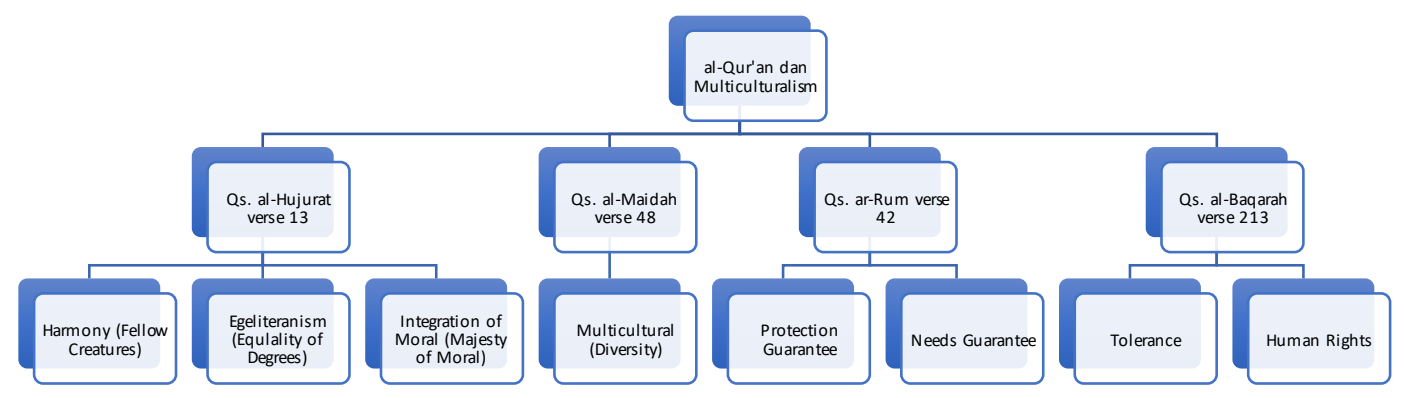

\section{Conclusions}

Conclusions. The idea of multiculturalism is an idea that emerged in the 1970s and developed rapidly throughout countries with different backgrounds of socio-political conditions. However, the basic values of the formation of multiculturalism have existed since 14 centuries ago. Where the holy al-Qur'an separately in each verse describes and accommodates the basic values that make multiculturalism exist.Basically, the values of equality, justice, tolerance and all the terms that refer to these things have been described in the Qur'an. In simple terms, it can be said that the true reality of multiculturalism already exists in Islamic teachings, to be precise in the holy book of the Koran. So by understanding every item of the values of the Qur'an can make every individual, group, nation that leads the nation to be more advanced in a civilization that upholds the noble values of humanity. 
Acknowledgements. There is no reply that the author can give other than prayer and thanks, may Allah SWT accept good deeds, give His pleasure to us, give a reward worthy of all his efforts and hopefully all of us in His protection. Gosh. The author is fully aware that this journal is far from perfection. Therefore, both suggestions and criticisms from readers are very authors expect for further improvement. Finally, the authors express gratitude to Allah SWT very deeply and hopefully this journal is useful for writers in particular and to all parties in general.

\section{References}

[1] Azra, A.: Identitas dan Krisis Budaya, Membangun Multikulturalisme di Indonesia. (2010)

[2] Baubock, R.: The challenge of Diversity Integration and Pluralism in Social of Immigration, Vermont. Pp. 157. Avebury (1996)

[3] Joshua M. Roose and Shahram Akbardazeh Muslims.: Multiculturalism and the Question of the Silent Majority. Vol. 31, No. 3, pp. . Journal of Muslim Minority Affairs, (September 2011)

[4] Jupp, J.: Politics Public Policy and Multiculturalism and Integration a Harmonious Relationship. Australian Press. pp. 42. Canberra (2011)

[5] Masduki, H.: Pluralisme dan Multikulturalisme dalam Perspektif Kerukunan antar Umat Beragama : telaah dan Urgensinya dalam Sistem Berbangsa dan Bernegara., Vol. 9, No. 1, pp. 40. Jurnal of Sosiologi (Juni 2016)

[6] Moqdood, T.: Multiculturalism Themes for Twenty Centuries Series. Polity Press. pp. London (2007)

[7] McGhee, D.: The End of Multiculturalism Terrorism, Integration and Human Rights. McGraw Hill Education. pp. 1. London (2008)

[8] M. Quraish Shihab, M.: Tafisr al-Misbah Pesan, Kesan dan Keserasian alQur'an,. Lentera Hati. pp. 115. Jakarta (2002)

[9] Nurdin, A.: Kegagalan Politik Multikulturalisme dan Pelembagaan Islamofobia di Negara-Negara Barat. Vol. 2, No. 4, pp. 1. Jurnal of Ilmu Ushuluddin (Juli 2015)

[10] Parekh, B.: Rethingking Multiculturalism Cultural Divesity and Political Theory. Harvard University Press. pp. 6. Massachusetts (2002)

[11] Taylor, C.: Multiculturalism: Examining the Politics of Recognition. Pricenton. New Jersey (1994) 
[12] Yasin, N.: Multikulturalisme di Indonesia Menurut Al-Qur'an. Vol. 6, No. 2, pp. 34. Jurnal Studi Keislaman, (Desember 2019) 